\title{
Teeth Restoration for Overdenture Support
}

\author{
Snežana Brković 1 , Srdjan Poštić1, Dragan Ilić \\ ${ }^{1}$ Clinic for Prosthodontics, School of Dentistry, University of Belgrade, Belgrade, Serbia; \\ ${ }^{2}$ Clinic for Restorative Dentistry and Endodontics, School of Dentistry, University of Belgrade, Belgrade, Serbia
}

\begin{abstract}
SUMMARY
Introduction If patients have remained only a few teeth in one jaw, these teeth can be retained and specifically prepared to bear mobile supradental prosthesis i.e. overdenture (OD). The patients are usually very motivated to preserve remained teeth. The aim of this study was to present the plan, the preparation procedure and the treatment protocol for the remaining teeth that will bear full mobile OD.

Material and Methods Study included 12 patients and 23 remaining teeth. Treatment plan considered: radiological analysis and selection of the remaining teeth, reduction of the clinical crown of the teeth, endodontic and periodontal treatment and finally conservative or prosthodontic restoration of these teeth. Fifteen teeth were restored using cast crown build-up (cap) and eight teeth were restored with amalgam restorations. Patients who received twelve lower mobile full OD were observed for one year to assess the integrity of the extra alveolar tooth structure.

Results After observation period of one year, the integrity of crown restorations was maintained as well as the alveolar bone height.

Conclusion The restoration of the remaining teeth using cast crown build-up (cap) and amalgam is very important for maintaining extra alveolar tooth structure and successful treatment with overdentures.
\end{abstract}

Keywords: overdenture; abutment restoration; clinical crown reduction; tooth mobility; amalgam restoration

\section{INTRODUCTION}

Natural teeth loss is often followed by morphological and functional changes within the orofacial system. These changes include: supporting tissue reduction in jaws, decrease of biological functions of supporting (supportive) tissues, lack of proprioceptive signalization from periodontal tissues, disorders in the normal (basic) roles of orofacial and digestive system, discrepancy in normal jaw relation and disguised appearance of the face [1]. All aforementioned disorders decrease life quality of the patients and cause different psychical conditions [2]. These disorders complicate the manufacturing of the dentures and make the mastication apparatus less efficient causing farreaching consequences to the whole organism. Regarding to that, the therapeutic procedures that prevent excessive loss of jaw bone and contribute in keeping basic alveolar ridge height are important in dental practice $[1,3,4,5]$.

Research showed that remained teeth or their roots that bear overdenture can slow down the alveolar height loss, keep the sensorial functions of periodontal tissue around remained teeth hence precise regulation of mastication movements, more effective chewing cycle and protection of oral tissues from excessive mechanical irritations $[3,4$, 6-9]. In old-age patients there is often need to restore the missing part of amalgam restoration. Recent investigations pointed out to the benefit of only partial restoring of damaged amalgam using composite material. In endodontically treated teeth composite restorations show about $51 \%$ higher fracture strength in comparison to amalgam [10].
Since the patients with this type of treatment retain their remaining teeth they are highly motivated for success of whole treatment procedure $[2,9]$.

The aim of this study was to present the plan, the preparation procedure and the treatment protocol for the remaining teeth that will bear full mobile OD.

\section{MATERIAL AND METHODS}

Study included 12 patients of the Clinic for Prostho-dontics who had 25 remained teeth for restoration. The treatment protocol included: radiographic analysis and selection of hopeless teeth, reduction of the crowns of retained teeth, endodontic treatment, periodontal treatment of pockets and conservative (direct) and/or prosthodontic (indirect) restoration of extra alveolar tooth tissue. After radiographic analysis 23 teeth were retained and two were extracted as "hopeless". The criterion for extraction was the presence of alveolar bone height less than $3 \mathrm{~mm}$ (Figure 1).

The protocol was as follows:

\section{Measuring the Tooth Mobility Index (TMI)}

At the beginning of the treatment, the baseline values of the TMI (established by the School of Dentistry, Clinic for Periodontology and Oral Medicine, University of Belgrade) [11] using dental probe and bimanual palpation were recorded (Table 1). 


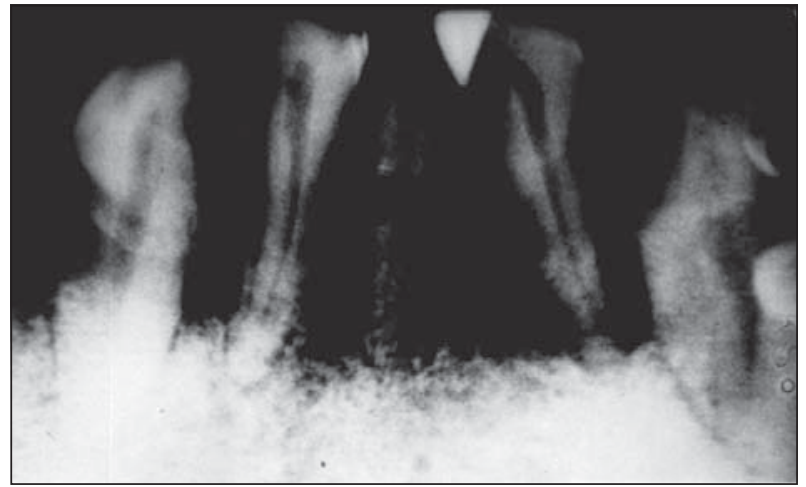

Figure 1. Hopeless teeth - radiography.

Slika 1. "Beznadežni” zubi - radiogram.

Table 1. The condition of the experimental teeth before tooth reduction in regard to vitality and tooth mobility index (TMI)

Tabela 1. Stanje eksperimentalnih zuba pre redukcije zubnog tkiva s aspekta vitaliteta i indeksa labavljenja zuba (ILZ)

\begin{tabular}{|c|c|c|c|c|c|}
\hline \multirow{2}{*}{$\begin{array}{c}\text { Vital teeth } \\
\text { Vitalni zubi }\end{array}$} & $\begin{array}{c}\text { Devitalised } \\
\text { teeth } \\
\text { Devitalizovani } \\
\text { zubi }\end{array}$ & \multicolumn{5}{|c|}{$\begin{array}{c}\text { TMI } \\
\text { ILZ }\end{array}$} \\
\cline { 3 - 7 } & 7 & $\mathbf{0}$ & $\mathbf{1}$ & $\mathbf{2}$ & $\mathbf{3}$ \\
\hline 16 & 7 & 3 & 16 & 1 \\
\hline \multicolumn{2}{|c|}{23} & \multicolumn{5}{|c|}{23} \\
\hline
\end{tabular}

\section{The clinical crown reduction}

The last remained teeth usually had large clinical crown and there was need for their gross reduction under adequate anesthesia (Figure 2).

\section{Endodontic procedure}

Endodontic therapy was performed in majority of teeth due to the preexisting pulp involvement or pulp exposure caused by crown reduction. Seven out of 23 teeth have been treated earlier and the rest 16 underwent endodontic treatment. Even though there are literature data about seldom endodontic treatment for molars that will bear OD (Figures 3a and 3b) [9], in this study, molars were not retained due to the complexity and high risk of this procedure.

\section{Periodontal preparation}

It included removal of dental plaque and calculus as well as the treatment of periodontal pockets.

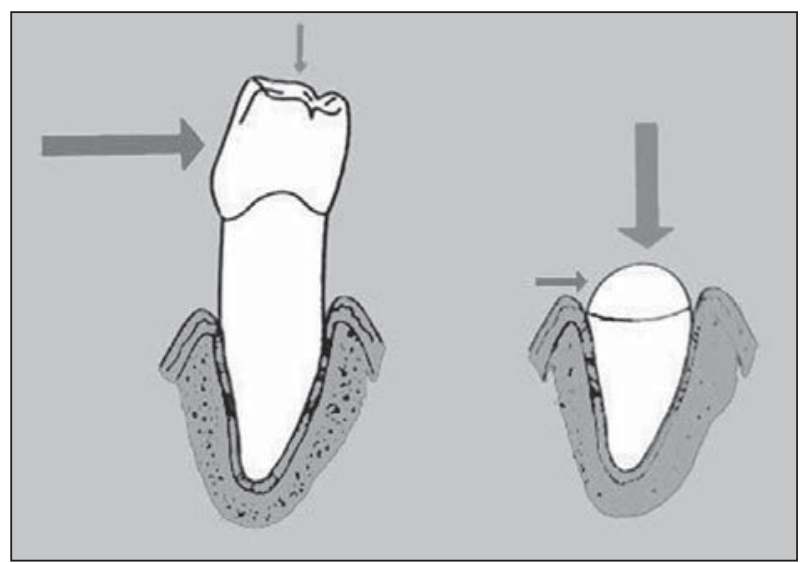

Figure 2. The reduction of clinical crown Slika 2. Redukcija kliničke krunice

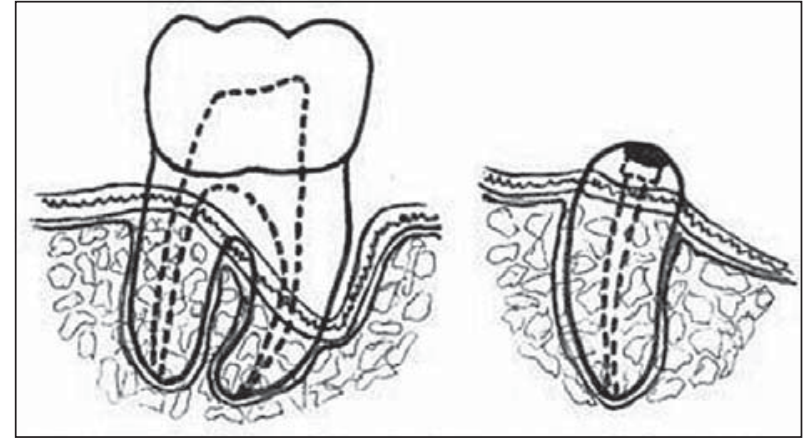

Figure 3a. Hemisection of molar teeth for overdenture support Slika 3a. Hemisekcija molara za potporu supradentalnoj protezi (SDP)

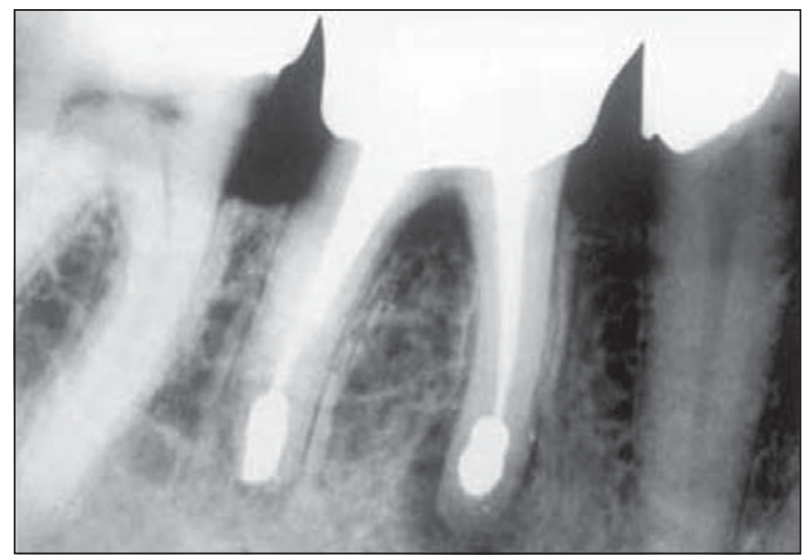

Figure $\mathbf{3 b}$. Radiography of the tooth indicated for hemisection Slika 3b. Radiogram zuba indikovanog za hemisekciju

\section{Conservative or prosthodontic restoration}

Restoration of extra alveolar part of the teeth was done by placing direct or indirect filling, not later than three weeks after endodontic treatment was completed. The temporary filling material was GIC. As majority of the cavities included at least one wall in the gingiva vicinity or below, eight teeth were restored by amalgam fillings as whole or partially. In cases where extra alveolar structure of the tooth was preserved, upon the rounding the crown abutment, amalgam filling was placed occlusally. In the teeth with gross composite restorations and satisfying quality in the coronal but with defect in gingival part, amalgam filling was placed in gingival region only. The shape of abutments with restorations was round or like rounded cone (Figures $4 \mathrm{a}$ and $4 \mathrm{~b}$ ). Cast restorations of Ir-Pt alloy were applied on 15 teeth (Figures $5 \mathrm{a}$ and $5 b)$. The choice was made in order to preserve the quantity of extra alveolar tooth structure. The teeth with circular gingival defect required cast cap restorations and their demarcation line was located on the restoration. These indirect filling had also shape of rounded cone.

\section{Manufacturing of mobile OD}

Soon after crown restoration by direct or indirect filling and their finishing as well as periodontal treatment OD was designed and manufactured.

\section{Measuring of TMI}

After the treatment was completed, TMI was recorded (Table 2). 


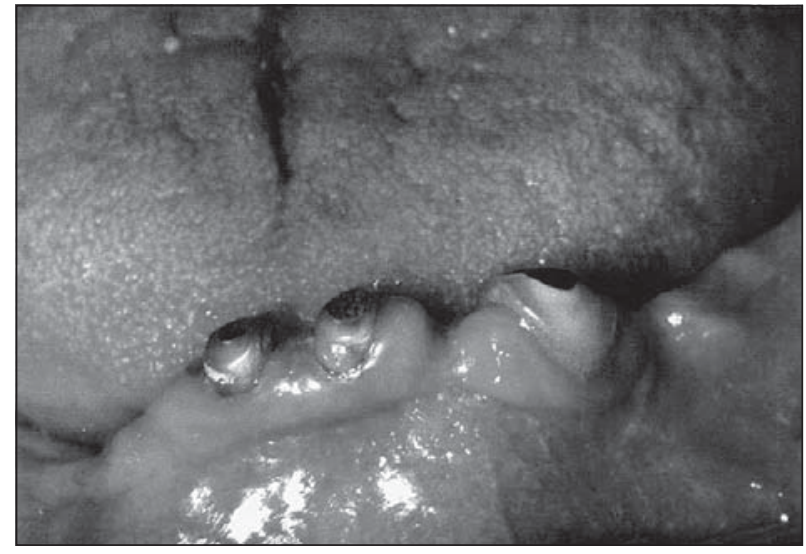

Figure 4a. Teeth restored with casting caps in a patient Slika 4a. Zubi zbrinuti livenim kapicama kod jednog pacijenta

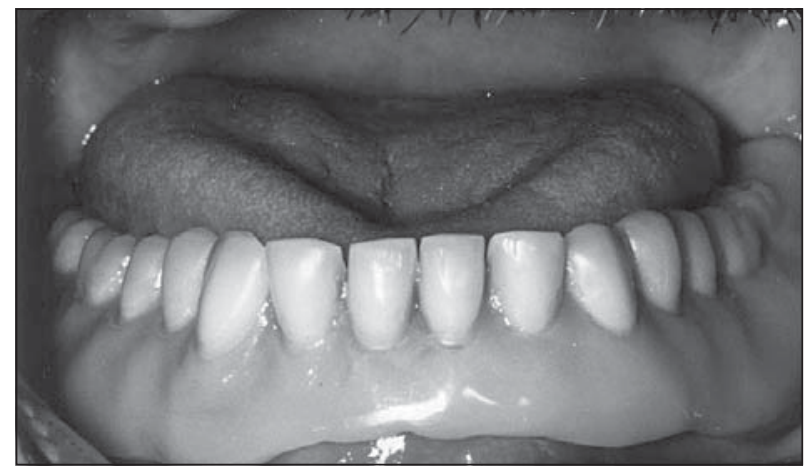

Figure 4b. Lower overdenture fabricated according to the teeth restored with casting caps in the same patient

Slika 4b. Donja totalna SDP urađena preko zuba zbrinutih livenim kapicama kod istog pacijenta

\section{Check-up appointment}

Integrity of restorations was summarized one year after the treatment completion (Table 3). During that time the patient used OD. Control check up considered a) TMI recording; b) marginal defects checks; c) second-

Table 2. The condition of the bearer teeth after tooth tissues reduction

Tabela 2. Stanje potpornih zuba posle redukcije zubnih tkiva

\begin{tabular}{|c|c|c|c|c|c|}
\hline $\begin{array}{c}\text { Intentional } \\
\text { devitalizati- } \\
\text { zation }\end{array}$ & $\begin{array}{c}\text { Devitalised } \\
\text { teeth } \\
\text { Devitalizovani } \\
\begin{array}{c}\text { Namenska } \\
\text { devitalizacija }\end{array}\end{array}$ & \multicolumn{5}{|c|}{$\begin{array}{c}\text { TMI } \\
\text { ILZ }\end{array}$} \\
\cline { 3 - 7 } & zubi & $\mathbf{0}$ & $\mathbf{1}$ & $\mathbf{2}$ & $\mathbf{3}$ \\
\hline 16 & 7 & 16 & 6 & 1 & 0 \\
\hline \multicolumn{2}{|c|}{23} & \multicolumn{4}{|c|}{23} \\
\hline
\end{tabular}

Table 3. The condition of the bearer teeth under OD after twelve months

Tabela 3. Stanje restauriranih zuba nosača SDP posle jedne godine

\begin{tabular}{|c|c|c|c|}
\hline \multicolumn{2}{|c|}{$\begin{array}{c}\text { Caries } \\
\text { Karijes }\end{array}$} & $\begin{array}{c}\text { Destruction of amalgam filling } \\
\text { or debonding of cast cap } \\
\text { Oštećenje amalgamskog ispuna i } \\
\text { rescementiranje kapice }\end{array}$ \\
\hline $\begin{array}{c}\text { Amalgam filling } \\
\text { Amalgamski } \\
\text { ispun }\end{array}$ & $\begin{array}{c}\text { Cast cap } \\
\text { Livene kapice }\end{array}$ & $\begin{array}{c}\text { Amalgam filling } \\
\text { Amalgamski } \\
\text { ispun }\end{array}$ & $\begin{array}{c}\text { Cast cap } \\
\text { Livene kapice }\end{array}$ \\
\hline 0 & 0 & 0 & 1 \\
\hline 0 & 0 & & 1 \\
\hline
\end{tabular}

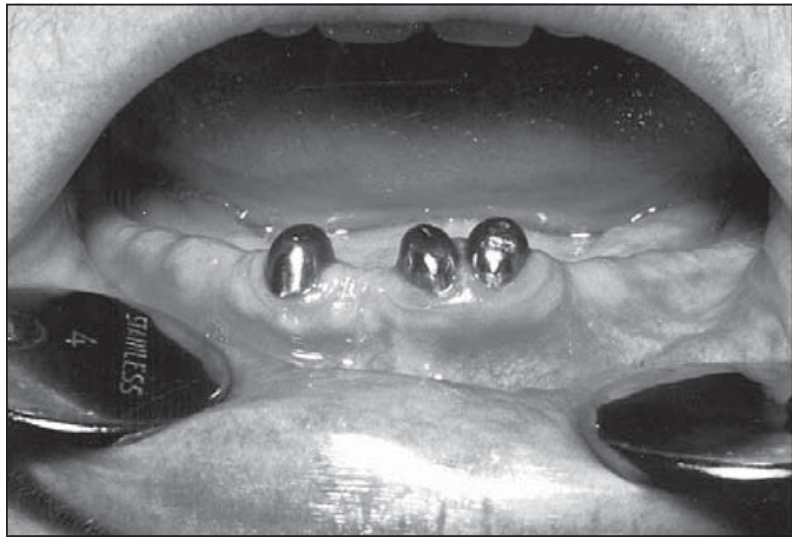

Figure 5a. Teeth restored with amalgam restorations in other patient Slika 5a. Zubi zbrinuti amalgamskim ispunima kod drugog pacijenta

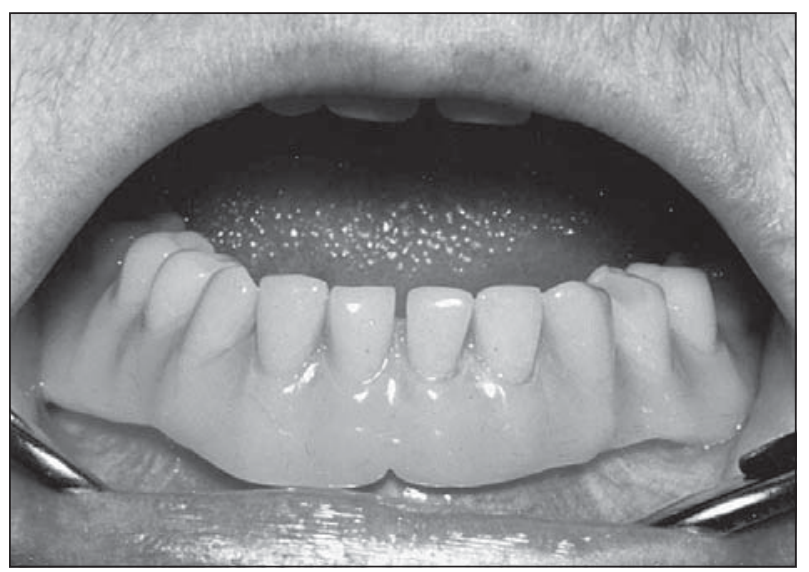

Figure $\mathbf{5 b}$. Lower overdenture fabricated according to the amalgam restored teeth in the same patient

Slika 5b. Donja totalna SDP urađena preko zuba zbrinutih amalgamskim ispunima kod istog pacijenta

ary caries incidence; and d) periodontal tissue condition checks using magnifying loupe of $4 \mathrm{x}$ power. When criterions b) and c) were satisfying, it was noted as good quality. If only one of two criterions was unsatisfying, it was noted as failure. During the same visit, the occlusion was checked and corrected, if needed.

Student t-test was used for comparison between the groups with confidentiality level of $\alpha=0.05$.

\section{RESULTS}

At the check-up appointment twelve month upon the base line findings (the beginning of the study) neither caries nor defect of marginal integrity of the restoration were noticed considering both amalgam and cast fillings. This was confirmed statistically by comparing these two restoration groups ( $p>0.05)$. There was no missing amalgam filling parts or complete fillings. One cast cap only was debonded (Table 3). Nevertheless, comparing the integrity of direct and indirect restorations statistically significant difference was not found ( $p>0.05$ ).

TMI recorded values did not expose significant difference between teeth restored with amalgam and cast caps $(\mathrm{p}>0.05)$. 


\section{DISCUSSION}

In this study the teeth that were subjected to crown reduction, endodontic and periodontal treatment became less mobile after the treatment. This could be explained by the fact that the crown reduction and periodontal treatment gave better crown/root ratio making that tooth more prone to resist twisting forces. The tooth becomes more suitable to amortize the loading that guarantees good control of position and movements of lower jaw and better masticatory efficiency. Also, a patient is becoming more comfortable and satisfied with his OD. During the cast cap manufacturing, one should pay attention to the size of extra alveolar tooth structure. If it is lower than $3 \mathrm{~mm}$ there is need for additional retention of cast caps by canal posts or parapulpal (dentinal) pins.

The importance of OD for keeping the alveolar height was shown in the six-year study where no significant alveolar ridge resorption was noted in eleven female patients [8]. Other authors also reported similar results about keeping the alveolar ridge height under OD, $[12,13,14]$. Ettinger and Krell [12] in their papers discussed the problems in the endodontic treatment of reduced teeth. They recommended keeping the teeth with minimal alveolar support, but still insisting that they do not retain all the teeth, only the ones that following the reduction of clinical endodontic crowns can be endodontically treated to serve as a valid support to OD.

The reason for giving the preference to mobile OD over traditional mobile denture can be found in our results from 1994 [3]. They can be summarized as superiority of OD over classical ones after comparison of the stability of 12 mobile OD vs. 12 classical dentures. The advantage of OD was confirmed by the results obtained at the end of observation period of one year. The comparison of the following parameters between these two groups was done in: gingival index, plaque index and teeth mobility index [3]. According to the values of GI, PI and TMI which were significantly different in teeth covered by overdentures as compared to teeth that were part of partial denture, inflammation and tooth mobility were more common in patients with conventional removable partial dentures. It may be concluded that the presence of classical partial dentures in patients with only few teeth remained can be more damaging to the supporting structures than the presence of OD in similar circumstances. Radiographical analysis performed in the same study did not indicate significant changes in the level of alveolar bone in any group, probably due to the relatively short observation period (one year). However, repeating gingival inflammation, poor hygiene and certainly greater mobility of teeth in patients treated with conventional removable partial dentures lead to the conclusion that they can also cause changes in alveolar bone [3].

In subjective evaluation, patients give absolute priority to OD over the conventional partial dentures due to superiority in stability, functional efficiency, greater comfort and variety of cosmetic benefits $[6,15]$. So, it is clear that the psychological factor plays an important role in patient adaptation to OD $[2,6,15]$. Considering OD as "special" and more successful than classical denture, patients are motivated to cooperate, especially in terms of maintaining oral hygiene knowing that it is the key to success of any dental restoration.

\section{CONCLUSION}

Restoration of the remaining teeth with cast and amalgam restorations showed equal success rate after observation period with minimal incidence of desintegrity of the applied crown restoration as well as alveolar bone height. In patients with good balanced occlusion and controlled gingival inflammation, tooth mobility can be well controlled. Even the teeth with minimal alveolar support can be retained.

\section{REFERENCES}

1. Zarb GA, Bolender CL, Eckert SE. Prosthodontic Treatment for Edentulous Patients: Complete Dentures and Implant-Supported Prostheses. St. Louis: Mosby; 2004.

2. Dimić-Potić J. Psihijatrija i stomatologija. Stomatološki glasnik Srbije. 1994; 41:171-2.

3. Brković-Popović S. Ispitivanje potpornog aparata ispod mobilnih supradentalnih proteza [magistarski rad]. Beograd: Stomatološki fakultet Univerziteta u Beogradu; 1994.

4. Brković- Popović S. Uticaj stalnog magnetnog polja na parodontalna tkiva ispod supradentalnih proteza [doktorska disertacija]. Beograd: Stomatološki fakultet Univerziteta u Beogradu; 2007.

5. Glišić B. Uticaj stalnog magnetnog polja na strukturu kosti rezidualnog alveolarnog grebena [doktorska disertacija]. Beograd: Stomatološki fakultet Univerziteta u Beogradu; 1990.

6. Brković-Popović S. Subjektivna evaluacija nosilaca supradentalnih proteza. Stomatološki glasnik Srbije. 2000; 47:95-8.

7. Brković-Popović S, Stanišić-Sinobad D, Poštić SD. Stanje alveolarne kosti u predelu zadržanih zuba u pacijenta sa donjom totalnom supradentalnom protezom - prikaz slučaja. Stomatološki glasnik Srbije. 2003; 50:82-7.

8. Brković-Popović S, Stanišić-Sinobad D, Poštić SD, Đukanović D. Radiographic changes in alveolar bone height on overdenture abutments: a longitudinal study. Gerodontology. 2008; 25:118-23.

9. Amzalag G, Batarec E, Schoendorf R. Protèses supraradiculaires: Overdentures. Paris: Editions CdP; 1988.

10. Geiger S, Paikin L, Gorfil C, Gordon M. Fracture resistance of endodontically treated teeth restored with combined composite-amalgam restoration. Quintessence Int. 2008; 39:e58-62.

11. Đajić D, Đukanović D, Stanić S, Kovačević K. Parodontologija (atlas). Beograd: Elit Medica; 2001.

12. Ettinger LR, Krell K. Endodontic problems in an overdenture population. J Prosthet Dent. 1988; 59:459-62.

13. Ettinger LR, Qian F. Abutment tooth loss in patients with overdentures. J Am Dent Ass. 2004; 135:739-46.

14. Basker R, Harrison A, Ralph J. Overdentures in General Dental Practice. 3rd ed. London: British Dental Association; 1993.

15. de Liz Pocztaruk R, Vidal RA, Frasca LC, Rivaldo EG, Gavião MB, van der Bilt A. Satisfaction level and satisfactory performance of patient rehabilitated with implant-supported overdentures. Rev Odonto Ciênc. 2009; 24:109-15. 


\title{
Restauracija potpornih zuba supradentalne proteze
}

\author{
Snežana Brković1, Srđan Poštić1, Dragan Ilić² \\ ${ }^{1}$ Klinika za stomatološku protetiku, Stomatološki fakultet, Univerzitet u Beogradu, Beograd, Srbija; \\ 2Klinika za bolesti zuba, Stomatološki fakultet, Univerzitet u Beogradu, Beograd, Srbija
}

\begin{abstract}
KRATAK SADRŽAJ
Uvod Kod pacijenata kod kojih je preostao mali broj zuba u jednom zubnom luku zubi se mogu zadržati u vilici, na poseban način pripremiti, a zatim se preko njih može izraditi mobilna supradentalna proteza (SDP). Kako pacijent zadržava preostale zube, on je obično veoma motivisan za uspeh celokupnog lečenja. Cilj ovog rada je bio da se prikažu plan, priprema i način restauracije preostalih zuba koji treba da čine potporu mobilnih totalnih SDP.

Materijal i metode rada Ispitano je 12 pacijenata sa ukupno 23 preostala zuba. Plan lečenja je obuhvatio: radiološku analizu i selekciju preostalih zuba, redukciju kliničkih krunica zuba koje treba zadržati, endodontsku pripremu i parodontološku obradu zuba i konačno konzervativnu ili protetičku restauraciju ovih zuba. Od preostalih zuba, 15 je pripremljeno livenim kapicama, a osam amalgamskim ispunima. Pacijenti su rehabilitovani izradom 12 donjih totalnih SDP i klinički praćeni godinu dana, kako bi se proverilo očuvanje ekstraalveolarne strukture zuba.

Rezultati Rezultati dobijeni nakon godinu dana pokazali su da nije došlo do destrukcije nijedne krunične restauracije, a pri tom je inicijalna visina alveolarnog grebena bila očuvana.

Zaključak Na osnovu rezultata ovog istraživanja može se zaključiti da je restauracija livenim kapicama i amalgamskim ispunima značajan faktor u očuvanju ekstraalveolarne strukture zuba, a samim tim i validan način za očuvanje potpore SDP.

Ključne reči: supradentalna totalna proteza; restauracija patrljka; redukcija kliničke krunice zuba; labavljenje zuba; amalgamska restauracija
\end{abstract}

\section{UVOD}

Gubitak prirodnih zuba praćen je značajnim morfološkim i funkcionalnim promenama u okviru orofacijalnog sistema. Ove promene obuhvataju: redukciju potpornih tkiva u gornjoj i donjoj vilici, smanjenje bioloških vrednosti potpornih tkiva, gubitak proprioceptivne signalizacije parodoncijuma, poremećaje u odvijanju osnovnih funkcija orofacijalnog sistema, remećenje normalnog odnosa vilica i izmenjen izgled i izraz lica [1]. Konačno, sve ovo doprinosi nezadovoljstvu pacijenta i često menja njegovo psihičko stanje, koje remeti kvalitet njegovog života [2]. Ovakve promene značajno otežavaju izradu odgovarajućih nadoknada i značajno umanjuju funkcionalnu efikasnost mastikatornog organa, što ima dalekosežne posledice na čitav organizam. Zbog toga su svi terapijski postupci koji sprečavaju prekomernu redukciju kosti i doprinose očuvanju inicijalne visine alveolarnih grebenova predmet posebnog interesovanja u stomatološkoj nauci i struci $[1,3,4,5]$.

Istraživanja su pokazala da se zadržavanjem prirodnih zuba ili njihovih korenova i izradom mobilnih supradentalnih proteza (SDP) preko njih znatno smanjuje proces redukcije alveolarne kosti, te obezbeđuju očuvanje senzornih informacija iz parodoncijuma preostalih zuba, precizna regulacija mastikatornih kretnji, efikasnije žvakanje i zaštita oralnog tkiva od preteranih nadražaja $[3,4,6-9]$. Često se kod starijih pacijenata ukazuje potreba za samo delimičnom nadoknadom izgubljenog dela starog kruničnog amalgamskog ispuna. Novija istraživanja ukazuju na mogućnost delimične zamene samo nedostajućeg dela amalgamskog ispuna kompozitnim, što olakšava restauraciju velikih oštećenja krunice. U ovakvim slučajevima restauracije endodontski tretiranih zuba dobija se ispun čija je otpornost na prelom veća u proseku za 51\% u odnosu na čist amalgamski ispun [10].

Da je motivacija pacijenata da se podvrgnu ovim intervencijama i istraju veoma važna za uspeh celokupnog lečenja pokazuju istraživanja u kojima se pacijenti savetuju da zadrže svoje poslednje preostale zube preko kojih se izrađuju mobilne protetičke nadoknade (mobilne klasične ili SDP) [2,9].

Cilj rada je bio da se prikažu plan, priprema i način restauracije preostalih zuba u vilici koji će biti potpora mobilnoj SDP.

\section{MATERIJAL I METODE RADA}

Ispitano je 12 pacijenata Klinike za stomatološku protetiku Stomatološkog fakulteta u Beogradu kod kojih je bilo neophodno uraditi restauraciju preostalih 25 zuba. Plan lečenja je obuhvatio: radiološku analizu i selekciju preostalih zuba, redukciju kliničkih krunica zadržanih zuba, njihovu endodontsku pripremu, parodontološku obradu džepova i konzervativnu ili protetičku restauraciju ekstraalveolarnog dela zuba. Na osnovu analize retroalveolarnih radiografskih snimaka odlučeno je da se zadrže 23 zuba; dva su proglašena „beznadežnim”, te su ekstrahovana. „Beznadežnim” su proglašavani svi zubi sa potporom alveolarne kosti manjom od $3 \mathrm{~mm}$ (Slika 1).

Protokol rada je obuhvatio sledeće faze:

\section{Merenje indeksa labavljenja zuba (ILZ)}

Na početku eksperimentalnog perioda izmeren je ILZ (Klinike za parodontologiju i oralnu medicinu Stomatološkog fakulteta u Beogradu) [11] stomatološkom sondom ili bimanuelnom palpacijom (Tabela 1).

\section{Redukcija kliničke krunice}

Kako su poslednji preostali zubi obično oni s ogromnom kliničkom krunicom, često je vršena velika redukcija zubnog tkiva uz primenjenu adekvatnu anesteziju (Slika 2).

\section{Endodontski tretman}

Po pravilu je sledio kod većine zuba, jer je redukcija kliničke krunice vršena na nivou gde se ugrožava ili je već bio ugrožen 
integritet pulpe. Kod sedam preostalih zuba već je bila urađena devitalizacija, a kod 16 to je urađeno namenski. Nakon mehaničko-medikamentne obrade kanala, izvršena je opturacija kanala korena tehnikom lateralne kompakcije gutaperke. Iako u literaturi ima navoda da su se izuzetno retko endodontski zbrinjavali čak i molari za potporu SDP (Slike 3a i 3b) [9], u našem istraživanju to nije urađeno zato što je to za pacijenta veoma složen, a ponekad i rizičan zahvat.

\section{Parodontološka priprema}

Podrazumevala je uklanjanje čvrstih i mekih naslaga, kao i konzervativnu parodontološku obradu tvrdog i mekog zida džepa.

5. Konzervativna ili protetička restauracija ekstraalveolarnog dela zuba

Restauracija ekstraalveolarnog dela zuba primenjenim direktnim ili indirektnim ispunima vršena je nakon završenog endodontskog lečenja, odnosno u periodu ne dužem od tri nedelje, uz prethodno aplikovan adekvatni privremeni ispun od glasjonomer-cementa. Kako je većina kaviteta imala jedan zid u blizini gingive ili ispod nje, odlučeno je da se osam zuba zbrine amalgamskim ispunima u celini ili delimično. Tamo gde je bila očuvana ekstraalveolarna struktura zuba, nakon zaobljavanja patrljka, okluzalno je po potrebi postavljen amalgamski ispun. Kod zuba sa velikim kompozitnim restauracijama, kvalitetnim u kruničnom, a defektnim u gingivnom delu, restorativni retretman urađen je amalgamskim ispunom samo u gingivnom delu. Spoljni izgled preparisanog (zaobljenog) zuba sa ispunom ličio je na odsečak lopte ili zaobljenu kupu (Slike 4a i $4 \mathrm{~b})$. Livenim kapicama je restaurisano 15 zuba upotrebom standardne legure paladijuma (Slike 5a i 5b). Razlog za izbor livene kapice kao restaurativnog ispuna bio je očuvanje ekstraalveolarne strukture zuba. Kod zuba čiji su vratovi bili oštećeni cirkularnim karijesom urađene su livene kapice. Njihova demarkaciona linija morala je biti formirana u ispunu. Kod ovih indirektnih livenih ispuna spoljni izgled preparisanog (zaobljenog) zuba s livenom kapicom bio je sličan kao i kod amalgamskih restauracija u obliku zaobljene kupe.

\section{Izrada proteze}

Ubrzo nakon krunične restauracije zuba direktnim ili indirektnim ispunima, njihove završne obrade i uklanjanja naslaga usledila je izrada mobilne totalne SDP.

\section{Merenje ILZ}

Urađeno je posle izvedenog tretmana i izrade SDP sa dobijenim linearnim vrednostima (Tabela 2).

\section{Kontrolni pregled}

Eksperimentalni opservacioni period trajao je godina dana i pacijenti su sve vreme preko tako pripremljenih zuba nosili mobilne totalne SDP. Kontrolni pregled je podrazumevao: a) potvrđivanje novih vrednosti ILZ; b) analizu integriteta rubnog zatvaranja; c) utvrđivanje sekundarnog karijesa postojećih nadoknada; i d) utvrđivanje stanja potpornih tkiva (Tabela 3). Ispuni koji bi zadovoljili parametre pod b) i c) opservacijom pomoću lupe pri uveličanju od četiri puta, tj. ukazali na dobro rubno zatvaranje ispuna i izostanak sekundarnog karijesa, označeni su kao kvalitetni. Ispun koji nije zadovoljio makar jedan od pomenutih parametara integriteta označen je kao neuspeh. Prilikom pregleda takođe je kontrolisana i po potrebi korigovana okluzija.

Za statističku obradu dobijenih rezultata primenjen je Studentov t-test za poređenje grupa uzoraka sa nivoom poverenja od $\alpha=0,05$.

\section{REZULTATI}

Na kontrolnom pregledu načinjenom posle godinu dana nisu ustanovljeni karijes i oštećenje marginalne adaptacije ni na jednom zubu restauriranom amalgamskim ispunima, odnosno livenim kapicama. Takođe nije zabeleženo nijedno oštećenje amalgamskog ispuna, a samo se jedna livena kapica rascementirala (Tabela 3). Poređenjem dobijenih rezultata integriteta amalgamskih ispuna i livenih kapica nije zabeležena statistički značajna razlika ( $\mathrm{p}>0,05)$.

Vrednosti ILZ nisu bile statistički značajno različite u grupi zuba s ispunima od amalgama i onim s livenim kapicama ( $p>0,05)$.

\section{DISKUSIJA}

Tokom istraživanja primećeno je da su se zubi učvrstili nakon redukcije kliničke krunice, endodontskog lečenja i parodontološke obrade. Ovo se može objasniti time da se redukcijom kliničke krunice i parodontološkom obradom dobija povoljniji odnos kliničke krunice i korena, tako da taj zub postaje sposobniji da se odupre silama koje teže da ga pomere iz ravnotežnog položaja. Zub takođe postaje otporniji tokom funkcije, što obezbeđuje bolju kontrolu položaja i pokreta donje vilice i veću efikasnost žvakanja. Pacijent je samim tim sigurniji i zadovoljniji svojom postojećom mobilnom SDP.

Kod izrade livenih kapica neophodno je obratiti pažnju na veličinu ekstraalveolarnog dela zuba. Ukoliko je on $3 \mathrm{~mm}$ i manji, potrebno je obezbediti dodatnu retenciju livenim kapicama kanalskim ili parapulpnim kočićima. Na taj način ova ekstraalveolarna restauracija u vidu livene kapice postaje stabilnija i otpornija na dejstvo sila smicanja.

U prilog činjenici da totalne mobilne SDP imaju značajnu ulogu u očuvanju visine alveolarnog grebena pokazuje i studija u kojoj posle šest godina nije uočena znatna resorpcija alveolarne kosti kod 11 pacijentkinja [8]. Slične rezultate ispitivanja očuvanja parodontalnih tkiva ispod mobilnih SDP dobili su i drugi autori [12, 13, 14]. Etinger (Ettinger) i Krel (Krell) [12] u svojim radovima razmatraju i endodontske probleme u zbrinjavanju ovakvih redukovanih zuba. Oni takođe preporučuju zadržavanje zuba sa minimalnom alveolarnom potporom, ali pri tom insistiraju na tome da se ne zadrže svi zubi, već samo oni koje je nakon redukcije kliničke krunice moguće endodontski zbrinuti, kako bi poslužili kao valjana potpora SDP.

O prednosti mobilne SDP nad klasičnom mobilnom protezom govore i naši rezultati iz 1994. godine [3]. Oni se mogu rezimirati nalazima gde je poređenjem stabilnosti 12 mobilnih SDP prema 12 klasičnih mobilnih proteza zabeleženo preimućstvo ovih prvih. Prednost SDP potvrđuju i rezultati dobijeni na kraju perioda posmatranja od jedne godine koji su podrazumevali poređenje sledećih parametara između ovih dveju grupa ispitanika: gingivalnog indeksa (GI), plak-indeksa (PI) i ILZ [3]. Sudeći prema vrednostima GI, PI i ILZ, koji su se značajno razlikovali kod zuba koji su prekriveni sa SDP u odnosu na zube koji su u sklopu parcijalne pločaste proteze, zapaljenjske reakcije i mobilnost zuba su bili mnogo češći kod ispitanika sa klasičnim parcijalnim protezama. S tim u vezi se može zaključiti da je postojanje klasične parcijalne proteze kod pacijenata sa krezubošću štetnije za potporni aparat preostalih zuba od postojanja SDP u sličnim uslovima. Rezultati radioloških 
istraživanja i načini zbrinjavanja preostalih zuba ne ukazuju na značajne promene u nivou alveolarne kosti kod obe grupe ispitanika verovatno zbog relativno kratkog opservacionog perioda (godina dana). Međutim, ponovljena zapaljenja gingive u lošim higijenskim uslovima i svakako veća mobilnost zuba kod pacijenata kojima je ugrađena klasična parcijalna proteza navode na zaključak da nošenje ovih nadoknada u određenim uslovima može dovesti i do promena na alveolarnoj kosti [3].

Da je SDP laka za nošenje potvrđuje i studija o subjektivnoj proceni ispitanika, gde joj pacijenti daju apsolutnu prednost nad klasičnim parcijalnim protezama, navodeći superiornost faktora stabilnosti, funkcijske efikasnosti, veći komfor i razne estetske prednosti $[6,15]$. Na osnovu svega ovoga jasno je da psihološki faktor ima značajnu ulogu u adaptaciji pacijenata na ovu vrstu nadoknade $[2,6,15]$. Smatrajući SDP nekom „specijalnom” i uspešnijom vrstom nadoknade, pacijenti su motivisani za saradnju, posebno u pogledu održavanja oralne higijene, koja je ključ uspeha svake zubne nadoknade.

\section{ZAKLJUČAK}

Restauracija preostalih zuba amalgamskim ispunima i livenim kapicama pokazala je jednako dobre rezultate nakon opservacionog perioda uz veoma malu incidenciju oštećenja kruničnih restauracija i očuvanje visine alveolarnog grebena. Kod pacijenata sa dobrom okluzijom i kontrolisanom inflamacijom blag stepen labavljenja zuba se može kontrolisati. U takvim slučajevima dozvoljeno je zadržavanje i zuba sa minimalnom alveolarnom potporom. 